\title{
Filching Commonality by Translation of Proverb in Indian Linguistic Scene*
}

Biswanandan Dash

\begin{abstract}
$\underline{\text { Abstract }}$
An analogy between learned expertise and knowledge dissemination through translation is a pervasive and enduring feature of modern culture. The aim set to this paper is to replace the translation within the broader perspective of a macro-level dynamics, so as to exhibit its common relationships in Indian multilingualism scene. We start by recalling that translation does not seem in a vacuum, however, emerges in the long juggling affair at micro-level. Hence, the demand for translation must not be over-ruled. At the same time, translation contributes to the maintenance and development of linguistic diversity. Instinctively, this study makes a reticent attempt to tackle and observe how commonality of proverbial expressions can occur in the process of translation between Marathi and Odia. For this, we have randomly chosen a few proverbs to counter affinity on a think-aloud protocol. Finally, the results say that there is a tremendous amount of commonality between the languages and its culture.
\end{abstract}

Key words: Proverb; Text-typology; Commonality, Equivalence; Wordfor-word translation; Sense-for-sense translation; lingua-culture translation; parallel translation

\section{Introduction}

Culture continuously transmits and imputes through the language. Recognizing the primary importance that the individuals place their own language fosters in true participation for the language development. Culture and language are therefore rooted in 
each other. It is not easy to separate the two as each language born out of its cultural context.

Naturally, diversity of languages creates potential in thinking, expressing and thus opening a whole vista of ways to others. In Linguistic hegemony of translation, we tend to study the categories of things and causative processes from the angle of an individual, who uses the language as a product of specific cultural milieu (Ives, 2004: 16-23 \& 85). We tend to argue that we are not only dealing with linguistic hegemony but also with discursive hegemony (attempt to transform utterances from one discursive context to another or reasoning, rather than by intuition) of proverb translation.

In this way, afterwards, a translation study was "clearly defined as a sub-discipline of applied linguistics" (Snell-Hornby, 1988: 15). It was centred on then with the concept of "equivalence" and later become a key concept of Translation Studies. Drawing upon the correspondences between two linguistic systems was one of the central tasks during this time (Snell-Hornby, 1988: 15; Hartmann, 1994; see e.g. Halliday, 1964 \& 1978). However, due to the incommensurability of linguistic structures, the actual translation always involved a shift, which "result from attempts to deal with systemic differences" (Baker, 1992), so many theories of translation at that time included in order to the systematization of translation shifts.

\section{The Problem}

While dealing with the proverb and its meaning, there have been issues for a long time in paremiological research (Mieder, 2004: 1-3). Proverbs are collective phenomena and building blocks 
of orality. They exist within a cultural context and convey the values and beliefs that shared in a community (White 1987: 152). The use of proverbs requires cognitive operations and their full meanings depend on the interactional context (Krikmann, 1974/1984). In comparison with its counterpart in the nominal sphere, this phenomenon has its crucial importance to any language possessing under the verb category and received a little attention in modern translation research. In a world bombarded by frivolous clichés, trivial multiword and godless sound bites, the expression of true wisdom is in supply today. For some truthful readers, as one can confess, "Proverbs seem banal or wrong". Obviously, "a truthful witness gives open testimony". For the logical mind the proverb seems to be a hodgepodge assemblage, having no rhyme or reason in a group of sayings used instantly as effective rhetoric in oral or written communication. Malevolently, proverbs admonish parents not to spare the rod, but state the welfare workers want to jail who obey or don't.

Indian proverbs may have been separated in many languages as per their forms and uses, nonetheless, in commonality they describe about some problems that are persisting through India. Translation in the Indian context becomes perplexing phenomenon since it is a multilingual area. In fact, the way that the local language milieu managed is provided, the translation tends to the promotion of local values and thoughts. It often directly contributes to a marginalization of language with its speakers (emphasized upon Pattanayak, 2014a: 437 \& 2014b: 441). Proverbs are folkish, the frozen expressions the way those formed and used as formulaic language, are rooted to decolonize the mind. They play an important role in creation of fictional realism within the communicative-pragmatics. Hence, they pose challenges to translation as there are ample theoretical approaches to establish in the realm of translation and proverbs in 
proper between Indian languages that too across cultures.

\section{Proverbs translation relates to cultural diversity and delineates a national culture in India}

Translation is an influential factor in intercultural communication because it transcends not only our cultural beliefs but also the values and manners for contextualization (Campbell, 2005: 29). For a translator, proverbs defy translation. A proverb depends on the sound and sense (Norrick, 1985: 78). It is so because for its fixed or fossilized form and gives them one of their defining characteristics, refers to sound (alliteration) or phoneaesthetic effect (rhythm). This cryptic importance has to be rendered, or at least recompensed. Sense coincides with inherent literal meaning. The following English proverb can be taken as an example: "Like father, like son (Oxford Dictionary of Proverbs, 2004: 106)", suggests the facet of heritability, i.e. it denotes that a son is similar to his father in appearance, manner or in any other

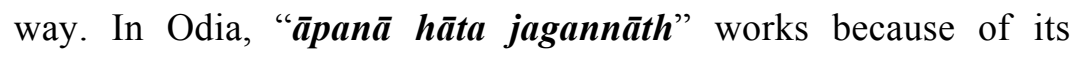
alliteration as well as for its good sense. The very proverb sounds and puns may not be caught in translation mostly to other than Indian languages. But "trust", the commonality in the word likes, "íshwar" or "bhagwān" with all your heart and do not lean upon your own understanding is not a truism to many. As such, the discipline in Proverbs is both doctrine and training. For those who either espouse linguistic relativity, what we call 'language' and 'culture', 'consciousness' and 'behaviour'. This develops and operates together though individually or as group experience. Since those do not function in complete isolation from each other or they can be considered separately. This interpretation is built upon triangulation as "lingua-culture", a joint phenomenon of languageculture. 


\section{Do the "Lingua-Culture" factors work together?}

It is of course true that each language is contextual. "Transmission of culture, like the transmission of language abilities, poses a knotty problem" (Pattanayak, 2014b: 444). Thus, we cannot eliminate perfectly formed expressions plus whatever other societal trends become involved within them. As Norrick (1985) and Mieder (2004: 4-5) shed light on the proverbs need attention because (i) they are there: a significant part of language; (ii) they have a special status as "both form-meaning units and analyzable complexes of independently occurring units"; and (iii) they "unite properties of the sentence and the text." Generally, these determine how people say such moral wisdom with each other. Subjectively, we can't sound them the same meaningfully to other languages. Arising from fact, there is always a top priority for choosing the appropriate equivalence within the texts that can directly be understood. Hence, we argue that cultural approximation strategies, such as functional equivalence or what we term "lingua-culture translation" can be the best choice in translating culture specific terms i.e. proverbs and proverbial expressions.

\section{Rationale and Purpose}

It is very axiomatic to infer that the translatability of proverbs, proverbial idioms, idiomatic expressions, is quite problematic and challenging due to their strangeness and complexities. Most of these proverbs comprehend with difficulty and sound unintelligible even for the people in the same culture (Baker, 1992: 68). Other factors include, for example, the significance of the specific lexical items which constitute the proverb, i.e. whether they are manipulated elsewhere in isolation or in the source text of using idiomatic language in a given register in the target language. 
Until 1991s, the work of Peter Newmark (1981: 107) has been prominent in the scholarship of translation theory for several years. His transfer postulates a fussy theorization about the strategies to be adopted for translating, i.e. the translation of proverbs in nonliterary texts is straightforward if the TL has a recognised equivalent. Otherwise, the translator has the option either of translating the foreign proverb and showing its reference to the text, or of absorbing the proverb in the text which "usually... proceeded largely in an empirical vacuum" (emphasised in Dash, 1992: 58). Hopefully, Newmark refers to the "non-literary texts" as in isolation, but the irony is that his remarks not distinctively substantiate with any examples by "absorbing the proverb in the text", especially, with reference to Indian languages. An obscure literary proverb should not be translated into a very familiar proverb, if available in the target language. Similarly, Pattanayak (2014a: 439) stresses on the proverb translation is that if the translator is fully conversant with the structural make up of both the languages then s/he must make an effort to recreate the style of original in translation. Otherwise unavailable, it must consider the inner voice of the original and express by suitably adapting. However, Prof. Pattanayak's proposition outruns the nicety without exemplifying more from proverb translation as to how it can be among Indian languages (Pattanayak, 2014a: 437-440). It is best to prefigure the equivalence between the proverbs standing within the context of the source culture and the target. The wise ways to follow other strategies as it fit to the best are,

"Transposition" is a change of word class that does not affect the overall meaning of the message what theoretically suggested by Darbelnet (1995: 97, see Hatim \& Munday, 2004). 
"Modulation", is opposed to meaning-preserving transposition, Vinay and Darbelnet (1958: 51, see Hatim \& Munday, $2004)$ and can be compared to rhetorical values.

"Equivalence" is the procedure of modulation that leaves upon semantically to link between the source and the target items, a replacement of the entire message by completely different lexical, stylistic, and structural means. This use of the term "equivalence" is quite different from the way it is normally understood in translation studies (see Hartmann, 1994: 292).

"Adaptation" tries to consider the limit of extreme reduction when the entire situation described in the source message that does not exist in target culture, what might lead the translator to adapt the situation so that the translation retains a similar event as the original (Gopalakrishnan, 2005: 1).

"Diction Alteration" is a kind of residual category of shifts that are neither additions nor subtractions. Among these are for instance adjustments at the level of diction, which should be made straightforward transliteration.

"Integration or Assimilation" is to host the cultural terms as it is.

"Paraphrase by footnote" is a (sum up) strategy by footnoting the unavoidable fictional text to nonfictional glossing in your own words while translating to target language in your own best explaining words (Sanchez Ortiz, 2015: 112). Here one should be careful about infringement if they alter a text's wording to avoid a claim of copyright. 
Mostly, culture-specific terms lack a corresponding point in the target language then paraphrase strategy can be adopted. Here, the words should be explained by unpacking their meanings using unrelated words.

\section{Methods, Procedures and Analysis}

There are different names to "proverb" used by the people of India in their own language. They have been collected and studied for centuries as informative and useful linguistic attributes of cultural values and thoughts. However, as we have restricted here only to Marathi and Odia so we give the equivalent terms used by both the languages. In Marathi the proverb is spoken as "mhaN, mhaNi, $\bar{a} N \bar{a}, \bar{a} h a N \bar{a}, v \bar{a} k p r a c h \bar{a} r, m \bar{a} h \bar{a} v a r \bar{a}$ and phurDuks" (Date, 1977; Narwane, 1978; Apte, 1990), whereas in Odia it is told as "prabāda, prabachan, vachana, Dhaga-DhmāLi, lokobāNí and kath $\overrightarrow{\boldsymbol{a}}$ " (Dash, 1971; Dash, 1985; Praharaj, 1990 cited in Dash, 1992: 47-57).

The corpus for this study has been extracted from a number of proverb compilation books, both in Marathi (Date, 1977; Narwane, 1978; Apte, 1990; Manwaring, 1991) and Odia (Dash, 1971; Dash, 1985; Praharaj, 1990 cf. Dash, 1992: 47-57). Out of all these, the present paper has taken to delimit a show-case with the illustrations in a descriptive perspective.

Pointing out pitfalls and opening up new perspectives, let us, therefore, turn our attention to the translation of proverbs in proper. For this reason, in what follows, we will try to translate some randomly chosen Marathi proverbs into Odia, considering its form and content. Side by side, we discuss the commonality and parallelism arising out of the process of translation in the comments 
by giving a four points ratings. 1 refers to "Best"; 2 given to "Better", 3 given as "Average" and 4 marked to "Poor". Their commonalty can be analyzed in the contexts of translation of production as a creative variation (see Langlotz, 2007) between Marathi and Odia.

Since, any proverbs deal directly with societal customs that might not translate directly to certain other societies or else the translated proverbs may be rejected by the target audiences (Dash, 1992: 97-98). In these cases, it might be helpful to find a proverbial saying that approximates the intended message of the diction so as to use that.

\begin{tabular}{|c|c|c|c|c|}
\hline SL & Marāthi Proverb & TL & $\begin{array}{l}\text { Odia } \\
\text { Translation }\end{array}$ & $\begin{array}{l}\text { Commonalty } \\
\text { Rating }\end{array}$ \\
\hline$\# 1$ & $\begin{array}{l}\text { apaNa mele āNi } \\
\text { jaga buDāle } \\
\text { (self death and } \\
\text { world drowned) }\end{array}$ & $\geq$ & $\begin{array}{l}\text { nije male } \\
\text { juga buDe } \\
\text { (self death } \\
\text { and world } \\
\text { drowned) }\end{array}$ & 2 \\
\hline
\end{tabular}

\section{Comments:}

The literal meaning of Marathi and Odia proverbs are same in sense. Both means, 'after my death, the world is drowned (How does it affect me?)'. This Odia translation shows the communicative commonness as in sense of Marathi. To preserve the inherent meaning we ignored the Marathi word " $\overline{\boldsymbol{a}} \boldsymbol{N} \boldsymbol{i}$ " means 'and'. However, there are a few Odia parallel proverbs used, such as:

Odia Parallel \#1:

"ākhi bujile duniā andhāra"

(Eyes if-closed world dark)

[Literal sense: When the eyes closed, the world became dark.] 

drown)

[Literal sense: If one dies the era closes, when another dies, one mourns for ever after.]

\begin{tabular}{|c|c|c|c|c|}
\hline SL & Marāthi Proverb & TL & Odia Translation & Rating \\
\hline$\# 2$ & 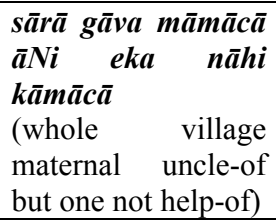 & $\geq$ & $\begin{array}{l}\text { gāaTā sārā māmu } \\
\text { mora, kintu goTie } \\
\text { nuhaMnti kāmara } \\
\text { (village-of whole } \\
\text { maternal uncle mine but } \\
\text { one not help-of) }\end{array}$ & 2 \\
\hline
\end{tabular}

\section{Comments:}

The original Marathi proverb means, the whole village is full of uncles but no one is helpful at the time of need'. The intended meaning of the proverb is, 'though there are many relatives but no one is useful at the time of need'. To retain the sense of the original, the translation has made to keep the pragmatic effect of the TL people's orality. Owing to this, there is a need to change the word order and added one word, "mora" in translating the proverb. However, for the above Marathi proverb, Odia does have a parallel proverb in use, such as:

Odia Parallel \#1: "gāMTā sārā buli äili, kehi na kahile basa boli"

(village-of whole round gave who not telling seat-to)

[Literal sense: The whole village (I) gave around but nobody told (me) to seat.] 


\begin{tabular}{|c|c|c|c|c|c|c|}
\hline SL & \multicolumn{2}{|c|}{ Marāthi Proverb } & TL & \multicolumn{2}{|c|}{ Odia Translation } & Rating \\
\hline \#3 & $\begin{array}{l}\text { āpalā } \\
\text { jagannāth } \\
\text { (own hand } \\
\text { Jagannath) }\end{array}$ & $\begin{array}{l}\text { hāta } \\
\text { Lord }\end{array}$ & $\geq$ & 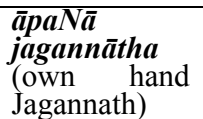 & $\begin{array}{l}\text { hāto } \\
\text { Lord }\end{array}$ & 1 \\
\hline
\end{tabular}

\section{Comments:}

The above Marathi proverb literally means, 'Own hands are our God' and the societal sense behind the use in their culture, refers to two in practice. The first one is that 'if any body goes to the Lord Jagannath Temple at Puri in Odisha, he would not find any sort of troubles in getting food to eat', whereas the second points to 'Self reliance'. This further means, if one does not do one's own work can not find the God (in result). In this, there is no translation attempt rather transposing the available Odia proverb to fit in. This shows a typical case as both the languages shared the communicative commonalty. However, if such proverbs are used within any literary text then the translator has to make an attempt to paraphrase it as per the sense hidden in the context.

\begin{tabular}{|c|c|c|c|c|}
\hline SL & Marāthi Proverb & TL & $\begin{array}{l}\text { Odia } \\
\text { Translation }\end{array}$ & Rating \\
\hline \#4 & $\begin{array}{l}\text { uthaLa paNyaālā } \\
\text { khaLkhaLäT phāar } \\
\text { (shallow water-to } \\
\text { sound great) }\end{array}$ & $\geq$ & $\begin{array}{l}\text { aLpa gabhira } \\
\text { pāNira śabda beśi } \\
\text { (shallow water-of } \\
\text { sound more) }\end{array}$ & 3 \\
\hline
\end{tabular}

\section{Comments:}

This Marathi proverb literally means, 'Shallow water caries more noise'. The sense refers to 'a person who knows little but poses more intelligent'. The Odia translation is a pragmatic attempt where there is no loss of meanings or sense to the original. However, a 
translator can also make use of the available parallel proverb in Odia, like:

Odiā Parallel: "phampā māThiāra śabda beśi" (Empty vessel-of sound much) [Literal means: Empty vessel sounds much.]

\begin{tabular}{|c|c|c|c|c|}
\hline SL & Marāthi Proverb & TL & Odia Translation & Rating \\
\hline$\# 5$ & $\begin{array}{l}\text { usābarobara } \\
\text { erMDāla pā } \mathbf{p i} \\
\text { (sugarcane-with } \\
\text { castor-oil plant-to } \\
\text { water) }\end{array}$ & $\geq$ & $\begin{array}{l}\text { äkhupāiM } \\
\text { gabagacha pāNi pāe } \\
\text { (sugarcane-for castor- } \\
\text { oil plant water get) }\end{array}$ & 3 \\
\hline
\end{tabular}

\section{Comments:}

The 'Castor-Oil plant gets water with the sugarcane plants' is the literal meaning of this Marathi proverb. The sense is that the neglected person always gets an advantage gratuitously at the time when the important persons get any benefit. The translation has carried out to retain the overall meaning in Odia of Marathi. Correspondingly to the sense an Odia proverb communicates, like:

Odiā Parallel: “dāLua lāgi kanaśiri pāNi pāe"

([a kind of-paddy] for Spinach-herb water get)

[Literal means: Spinach-herb gets water for paddy.]

\begin{tabular}{|l|l|l|l|c|}
\hline SL & $\begin{array}{l}\text { Marāthi } \\
\text { Proverb }\end{array}$ & TL & Odia Translation & Rating \\
\hline \#6 & $\begin{array}{l}\text { kāpa gele bhoke } \\
\text { rāhili } \\
\text { (ear-ring gone hole } \\
\text { remains) }\end{array}$ & $\geq$ & $\begin{array}{l}\text { Kānaphula sinā } \\
\text { jäichi, bindha rahichi } \\
\text { (ear-ring though gone } \\
\text { hole remains) }\end{array}$ & 4 \\
\hline
\end{tabular}




\section{Comments:}

Literal meaning of this proverb is 'the ear rings are gone but the hole remains'. In other words, this denotes though the prosperity has gone but the sign still exits. The verbosity is the ratio of words used in translation as compared to the number of words in its source. The translation is a "transposition" of an extra word, "sin $\overline{\boldsymbol{a}}$ ", in order to retain the phone-aesthetic tune of Marathi proverbial sentence structure. Odia too has a parallel proverb that communicates the same.

\section{Odiā Parallel:}

"karpura uDijäichi sinā kanā paDichi." (camphor smell gone but cloth laying) [Literal means: The camphor smell evaporated but the cloth is lying.]

\begin{tabular}{|c|c|c|c|c|}
\hline SL & $\begin{array}{l}\text { Marāthi } \\
\text { Proverb }\end{array}$ & TL & Odia Translation & Rating \\
\hline$\# 7$ & $\begin{array}{l}\text { barāti māgun } \\
\text { ghoDe, vyāhya } \\
\text { māgun piDhe. } \\
\text { (marriage } \\
\text { procession after } \\
\text { horse, } \\
\text { bridegroom's } \\
\text { after wooden } \\
\text { seat) }\end{array}$ & & $\begin{array}{l}\text { barajātri jibāpare } \\
\text { aNucha ghoDā, } \\
\text { samudhi jibāpare } \\
\text { deucha piDhā. } \\
\text { (marriage procession } \\
\text { gone-after getting horse, } \\
\text { bridegroom's gone-after } \\
\text { giving seat) }\end{array}$ & 3 \\
\hline
\end{tabular}

\section{Comments:}

Literal meaning of this proverb is 'what is the use of a horse after the marriage procession, like getting a seat after bridegroom father [honourable guest]'s departure?' The proverb denotes that it is termed as mockery if the things are not done in proper time. The translation is achieved to keep the phone-aesthetic diction besides retaining the figurative pun. The effort has been to bring the 
rhythmic tone to Odia translation by inducting few words, i.e. "jibāpare" (after going), "äNucha" (bringing) and "deucha" (giving). Apart from that there is another peculiar problem of cultural mismatch with the use of "ghoD $\overrightarrow{\boldsymbol{a}}$ " (horse) in Marathi which does not fit in the target culture as Odia people use "pāāliNki" (palanquin) instead of horse for their marriage procession or motor vehicle. It is an integration and assimilation of source customs with target culture. If we consider the sense of this Marathi proverb, then Odia people have few parallel proverbs, viz.

Odiā Parallel: "chora paLāilāru budhi diśe." (thief gone-after knowledge show) [Literal means: Sense comes when thief theft and left.]

\section{Conclusion:}

Beginning from the premise, the structural characteristics of proverbial expressions are unavoidable to any translator. This paper made an attempt to specify and retain the general nature of proverb. Structures, here what has been argued is constitute a mutual sustaining the cultural schemas that empowered with a communicative action and thus tried to reproduce them? Structure is dynamic, not static. It is continually a way evolving outcome and matrix of social interaction. Structures, which suggested here, are not reified as categories and invoked to explain the inevitable considerations of socio-cultural uses.

It's not a blatant lie, proverbial expressions are notoriously untranslatable between languages in India but one can be successful due to its lingua-culture. Baker (1992) proposed that if there is not an appropriate equivalent in target language, the translator should not force it into the translation. Hartmann (1994: 293), Baker (1998) 
and Newmark (1981: 107) believed that the target language equivalents should "replicate the same situation as in the original, whilst using completely different wording". This approach can be used to maintain the stylistic impact of the source text in the target text. According to them, the ideal method for the translator may be to approximate to target equivalents. These can be listed as follows: 1. Literal translation, 2. Original word in inverted commas, 3. Close equivalents and 4. Non-idiomatic translation. Contrary to some isolated opinions, there is obviously no simple answer to this, and it would be extremely obfuscation to make any grand claims when the proverb in proper is chosen for a particular situation, it is bound to fit perfectly to implicate an effective strategy for translation.

In the interim, indeed, we could not agree more and hope in my own 'embryonic' passion with the most challenging processes within languages that of translation. All may also agree to a great extent that it is up to the researcher and the translator how faithfully to mediate between expressed experience and expression among languages and cultures. It may be concluded that the transference of certain features are possible between source and target cultures. In this way, a complete equivalence is, more often communicative by neutralising the commonality when translating the proverbs is concerned.

Colophon: The most fervent thanks must go to my mentor, Professor Debi Prasanna Pattanayak, who has brought up me, a model of patience and encouragement for several years. In many ways he has gone above and beyond the role of my adjudicator and it is no exaggeration to say that without his support, this paper would have never taken this shape. Thanks must also go to Professor Omkar Nath Mohanty, former Vice-Chancellor of BPUT, Odisha for his inspiration in building my cognitive blocks in different ways 
during writing this paper.

* This is the revised and enlarged version of the paper presented at the Second National Language Conference, Bhubaneswar, India on 2nd April, 2015.

\section{REFERENCES}

Baker, M. 1992. In Other words: a course book on translation. London: Routledge.

Baker, M. (Ed.). 1998. The Routledge Encyclopedia of Translation Studies. New York: Routledge.

Campbell, S. 2005. English translation and linguistic hegemony in the global era (Pp.27-38). In: Anderman, G. and Rogers, M. (Eds). In and Out of English: For Better. For Worse? Clavedon: Multilingual Matters.

Dash, B. N. 1992. Problems of Translation Proverbs from Marathi to Oriya. (M. Phil. Dissertation). Hyderabad: University of Hyderabad.

Gopalakrishnan, P. N. 2005. Proverbs. Delhi: Authors Press.

Halliday, M.A.K. 1964. "Comparison and translation." In Halliday, M.A.K., McIntosh, M. and Strevens, P. The linguistic sciences and language teaching, London: Longman.

Halliday, M.A.K. 1978. Language as Social Semiotic: The Social Interpretation of Language and Meaning. London: Edward Arnold.

Hartmann, R.R.K. 1994. The Use of Parallel Text Corpora in the Generation of Translation Equivalents for Bilingual Lexicography (Pp.291-297). Euralex Proceedings of 1994. Retrieved from http://www.researchgate.net/publication/ 267239402

Hatim, B. \& Mason, I. 1997. The Translator as Communicator. London: Routledge. 
Hatim, B. \& Munday, J. 2004. Translation: An Advanced Resource Book. New York: Routledge.

Ives, Peter. 2004. Language and Hegemony in Gramsci. London: Pluto Press.

Krikmann, Arvo. 1984. On Denotative Indefiniteness of Proverbs: Remarks on Proverb Semantics 1. (Preprint-1). Tallinn: Academy of Sciences of the Estonian SSR, Institute of Language and Literature, 1974. Reprinted in Proverbium: Yearbook of International Proverb Scholarship 1: 47-91.

Langlotz, Andreas. 2007. Idiomatic creativity. Amsterdam: Benjamins.

Mieder, W. 2004. Proverbs: A Handbook. Westport, Connecticut: Greenwood.

Munday, J. 2001. Introducing Translation Studies. London: Routledge.

Newmark, P. 1981. Approaches to Translation. Oxford: Pergamon Press.

Norrick, N. 1985. How Proverbs Mean: Semantics Studies in English Proverbs. Berlin and New York: Mouton de Gruyter.

Ogden, G. S. 1977. 'The "Better" Proverb (Tob-Spruch), Rhetorical Criticism and Qoheletb.' JBL 96, 489-505.

Pattanayak, D. P. 2014a. "On Translation of the Vachanas" (Pp. 437-440). In Pattanayak, D. P. Language and Cultural Diversity (Vol-2). New Delhi: IGNCA/Orient BlackSwan.

Pattanayak, D. P. 2014b. "Language Competence and Culture Transmission" (Pp. 441-446). In Pattanayak, D. P. Language and Cultural Diversity (Vol-2). New Delhi: IGNCA/Orient BlackSwan.

Sanchez Ortiz, M. T. 2015. The Use of Footnotes in Literary Translation. FORUM: International Journal of Interpretation and Translation, 13: 1, 111-129, DOI: 10.1075/forum.13.1. 06san 
Snell-Hornby, M. 1988. Translation Studies: An Integrated Approach. Amsterdam: Benjamins.

Speake, J. (Ed.). 2004. Oxford Dictionary of Proverbs. Oxford: OUP.

Thompson, J.M. 1974. The Form and Function of Proverbs in Ancient Israel, The Hague and Paris: Mouton de Gruyter.

Vinay, J. P., \& Darbelnet, P. 1995. Comparative stylistics of French and English: A methodology for translation. (Translated by Sager, J.C. \& Hamel, J.C). Amsterdam and Philadelphia: Benjamins.

Waltke, Bruce K. 2004. The Book of Proverbs. Grand Rapids: Eerdmans.

White, Geoffrey M. 1987. "Proverbs and Cultural Models: An American Psychology of Problem Solving" (Pp. 151-172). In Holland, Dorothy and Quinn, Naomi. (Ed.). Cultural Models in Language and Thought. Cambridge: CUP. 